\title{
The Dynamics of Protest in Post Independence Indian English Women Fiction
}

\author{
Lata Mishra \\ Department of English,Government KRG Autonomous PG Girls' College,Gwalior, Madhya Pradesh \\ *Corresponding Author: dr.lata.mishra@gmail.com
}

Copyright (C) 2013 Horizon Research Publishing All rights reserved.

\begin{abstract}
Indian English women fictionists' perceptions of women's liberation and autonomy are deeply entrenched in the Indian women's situated-ness within the socio-cultural and economic spaces and paradigms of the nation. This paper studies the fiction of four representative novelists from India, writing in English language. Their women protagonists firmly refuse to become prisoners of orthodoxies, fossilized traditions and stereotypically idealized identities. These fictionists cast a sharp look at the fissures in the structural dynamics of society, functioning to the disadvantage of the female of the species. Protest in women's fictional narrative articulates both the existence of the dominant power structure and the female desire to disavow and defy that structure.
\end{abstract}

Keywords Protest, Resistance, Silence, Sexual liberation, Women, Society, Indian English Fiction

\section{Introduction}

India has a collectivist culture and patriarchal society. Social behavior, here, is determined largely by goals shared with some collective, and if there is a conflict between personal and collective goals, then, it is considered socially desirable to place collective goals ahead of personal goals. The origins of structures of inequality that lead to discrimination against women were found in pre- colonial Indian society with predominantly male -dominant social systems. However, they were institutionalized as a new legal structure during the colonial rule. Customs such as child marriage, dowry and widowhood rites have their origins in the pre-colonial era. These customs arose within a given social context that are impossible to be understood today because of the ideological shift that have occurred with colonization and the passage of time. The imposition of colonialism involved the construction of a system where women had less opportunity to participate in administration. Women, thus, belonging to weaker group from collectivist cultures, usually yield to the majority and dominating male group as the culture, places the higher value on harmony in person-to-group relations. On account of women's subordinate position men have gained economically, socially, culturally and politically.

Conformity to all social institutions in India is higher than its western counterparts that are more individualistic in nature. Patriarchal structures exert social influence, that produce compliance. Women, while privately retaining their personal view, conform to patriarchal set up in public, out of fear of appearing deviant or being ostracized or ridiculed by the society. However, with the increased social mobility, access to education and economic independence, breaking down of joint family system, conformity and submissiveness have been on decline. It has been replaced by independence and self-assertiveness. Cambridge Advanced Learner's Dictionary defines Protest as "a strong complaint expressing disagreement, disapproval, or opposition". The fiction under study reflects both Indian society and the individual. Protest in India comes in the form of resistance that may be viewed as a behavioral strategy having the potential to dislodge the dominant structure. This form of protest is non-confrontational and contestatory. Women's literature from India was not given due recognition and the required prominence in the literary scenario during the period of colonization. It is worth contemplating over the observations of Barker Chris, a culture critic, on Spivak about the reasons behind the marginalization of women's literature in the third world countries:

In a post colonial context, women carry the double burden of being colonized by imperial powers and subordinated by colonial and native men. Thus, Spivak (1993) holds that the 'subaltern cannot speak'. She is suggesting that poor women in colonial contexts have neither the conceptual language to speak nor the ear of colonial and indigenous men to listen. There are no subject positions within the discourse of colonialism which allow them to speak for themselves. (Barker, 2007:292).

Patriarchy's hegemonic character reaffirms the false consciousness in women that they are subordinate to and unequal with men. The process of internalization and 
dissemination of this ideology is so powerful that women lack their normal capacity to question this false consciousness. So they are pushed to the secondary status in the society as the "Other." Being deprived of the right to subjectivity they are also often relegated to the status of objects. They are conditioned to accept their subordinate status and to look down upon their own sex as secondary and lacking in certain qualities. This image of women as submissive and powerless derives from the vantage point of andocentric thinking. Feminist discourse confronts these assumptions of society as political and exposes the patriarchal mechanism that perpetuates these sexist notions. In this paper I attempt to examine the literary contributions of four leading twentieth century representative women writers from India. Anita Desai's (b.1937) Clear Light of Day and Fire on the Mountain, Shashi Deshpande's (b. 1938) The Dark Holds No Terror, Manju Kapur's (b.1948) Home and Namita Gokhale's (b.1956) Paro: Dreams of Passion have been selected for this study. Women in contemporary Indian English women fiction show multiple variations, colored by shifting ideological belief or predilection of the author.

\section{Methodology}

The works of selected novelists focus in their works on tradition / modernity dichotomy and the conflict between the 'foreign' and the 'local' in their societies. One of the objectives of this modest study is to trace out the analogous creative credo these novelists share and also decipher it through their masterpieces. The dualities woven in the fiction of these women authors, such as masculine vs. feminine, tradition vs. modernity, illusion vs. reality and self vs. other, become foreground with the use of the technique of counter- pointing one issue with the other connoting darker or brighter aspects of existence. The Paper examines the selected Indian English novels as feminist contributions to anthropology and sociology within the context of Indian culture. It begins with the premise that women have been defined by men and that if they attempt any deviation from the set norms they risk alienating themselves. It highlights the influence of culture on human social development by controlling human behavior and personality development. These feminist authors play a significant role in shaping anthropology and sociology by dealing in women's concerns.

Several critics have discussed victim dynamics in the works of Indian English women writers. These authors depict the social ethos of India by portraying the ways daughters grow up in households dominated by patriarchs and internalize the traditional structures of gender and power that eventually crushes their ambitions as they reach their youth. They strive to bring a paradigm shift in anthropology. Their creative output is often the result of social unrest and consequent protest against power structures in the society. They express their opinion, argue and protest through their fiction. Foucault examined cultures in terms of power relationships. The paper will analyze the man-woman relations and institution of marriage in the light of Foucault's theory of power. The selected novelists assert that ultimately every man-woman relationship is a power struggle. Sometimes it is explicit and other times imperceptible.

\section{Result}

Violence, both physical and mental, at homes is often defended as a means to 'discipline' its members. The selected authors show how 'women' has been discursively constructed as inferior on one and also threatening to man, on the other hand. Due to this, the male dominated society perpetually feels the need of containment and control of female body and mind and thus women are always subjected to particular disciplinary techniques. I contend that the work by these novelists have caused and facilitated individuals to change by providing solutions to prominent issues within society. They have allowed a "collective consciousness," which aids people in realizing that they may share a common discontent with patriarchal structure within society. They invite the readers to relate to the common necessity for change, which eventually helps achieve the goal of creating a "collective consciousness." Their fiction stimulates the readers to both want and demand change. They present the theme of tension between tradition and modernity, faith and reason and also psycho-social adjustment between the husband and wife in an artistic manner. The novelists desist from suggesting or depicting any radical changes in their novels. Rather, they show female characters subverting such discriminations in their own ways. Finally, their novels are often open ended so that the protest by the protagonists remains open for discussion. Language becomes a means to convert people to their cause by persuading personal and social change within society. Literature, in the hands of these writers becomes a means to empower and transform the individual by making the views of the women known. Literature replete with such a point of view often causes social evolution.

\section{Discussion}

\section{Section 1.1 Dismantling Patriarchal Metanarrative: Voice of the Silenced}

Foucault, in one of his interviews said:
Relations of power are not in themselves forms of repression. But what happens is that, in society, in most societies, organizations are created to freeze the relations of power, hold those relations in a state of asymmetry, so that a certain number of persons get an advantage, socially, economically, politically, institutionally, etc.And this totally freezes the situation. That's what one calls power 
in the strict sense of the term: it's a specific type of power relation that has been institutionalized, frozen, immobilized, to the profit of some and to the detriment of others. (Bess, 1988:1).

This section concentrates on the women who defy patriarchal notions that enforce them towards domesticity, they assert their individuality and aspire self reliance through education. They nurture the desire of being independent and leading lives of their own. They want to shoulder responsibilities that go beyond a husband and children. Such women are Bim, in Clear Light of Day and Saru in The Dark Holds No Terror. Patriarchy's hegemonic character reaffirms the false consciousness in women that they are subordinate to and unequal with men. The process of internalization and dissemination of this ideology is so powerful that women lack their normal capacity to question this false consciousness. In Foucault's words: 'the exercise of power perpetually creates knowledge and, conversely, knowledge constantly induces effects of power' (Foucault, 1980:52).The politics through which patriarchy imposes its authority and legitimizes its central position and push women to the periphery is exposed in this paper.

The fictionists open up avenues for their characters to find the true human self in them. They dig at the motif of male ideology in suppressing women and oppressing them at their work.

\section{Section 1.2 Bim in Clear Light of Day (1980):}

Bim, a girl child by deciding to become a heroine makes a clear statement about the possibilities that should be open to a woman. She aspires to develop in her, characteristics such as braveness and strength that have in Indian society been mainly regarded as male attributes. From an early age Bim, like her brother, Raja, has always been very keen on adventures and in addition soon develops a curiosity about learning ${ }^{1}$, none of which is regarded as particularly desirable for an Indian girl. Venturing into the outside world is something that is important to her in order to feel free and happy. Neither Raja's nor Bim's ideals for the future come true. While Raja, chooses to become a businessman, Bim charters her own destiny. She defies the roles given by patriarchal bastions and broaches the idea of woman's free decision not to marry. Foucault reflects, 'there are no relations of power without resistances; the latter are all the more real and effective because they are formed right at the point where relations of power are exercised' (Foucault, 1980:142). Bim's resistance neither predates the patriarchal power nor issues from a site out of it. Instead it depends upon and develops out of the situation against which it struggles. In her resistance Bim struggles to loosen the constraints on possibilities for action. She opposes the patriarchal tendency of normalizing-disciplinary power to confine individuals to their fixed identities.

As a lecturer in History, Bim is economically self-governing. She maintains a silence to cover up her pangs and sufferings. Even though she understands the gender discrimination in her childhood and Tara and Raja's selfishness in adulthood she maintains a silence. She carries the responsibility of her retarded brother and aged aunt single-handedly. The narrative space is infused with a new psychic life, an eloquence of silence. Bim negotiates the silence that represents first her alienation and then her freedom. She shifts from involuntary to voluntary silence, from repression to distancing. Here the silence is more eloquent than the loud speeches. Desai makes use of such silences to critique the hegemonic patriarchal narrative pattern. The incidents in Bim's life lead her to see things in clear light of day. The novelist explores the gender identities of the siblings, Bim, Raja and Tara as well as that of their aunt Mira, concentrating especially on the two sisters. It is particularly through role attribution, which is a characteristic of the novel, that female and male forms of identity are shaped. Towards the end of the narrative, Bim after exploding before her retarded brother Baba feels calm and remains rooted to her family. She holds herself responsible towards her family and reaches self actualization. She realizes:

Her own house and its particular history linked
and contained her as well as her whole family with
all their separate histories and experiences - not
binding them within some dead and airless cell but
giving them the soil in which to send down their
roots, and food to make them grow and spread,
reach out to new experiences and new lives, but
always drawing from the same soil. That soil
contained all time, past and future, in it. ${ }^{2}$

\section{Section 1.3 Saru in Dark Holds No Terrors (1980):}

Sarita (Saru) is torn between two worlds-one formed by the values and norms imposed by the patriarchal structure, and the other, her indomitable will to realize her self-worth on the face of all those traumatic experiences. Cognitive organization alongwith socialization aid children in learning their cultures and/or societies. They define their roles as men and women. This knowledge is then internalized as a gender schema, which settles as unchallenged core belief in an individual. According to Foucault, "truth is a thing of this world: it is produced only by virtue of multiple forms of constraint. And it induces regular effects of power' (Foucault, 1980:131). The present extract shows how a girl is socially conditioned by her family in Dark Holds No Terror:

That's important...A wife must always be a few feet behind her husband. If he is an M.A., you should be a B.A. If he is 5'-4" tall, you shouldn't be 5'3" tall. If he is earning five humdred rupees, you should never earn more than four hundred and ninety-nine. That's the only rule to follow if you

\footnotetext{
${ }^{1}$ Desai, Anita. Clear Light of Day (2001) p.123
}

\footnotetext{
${ }^{2}$ Desai, Anita. Clear Light of Day (2001) p.182
} 


\section{want a happy marriage. ${ }^{3}$}

During her young days, Saru, the protagonist is a victim of discrimination as her brother enjoys privileged position. She pursues her medical career against her mother's consent, she falls in love with low caste poet and her marriage meets with disapproval from her parents. her leaving home to marry Manohar who belongs to a lower caste which makes her parents disown her. As Saru progresses in her career her marital life becomes difficult. Manohar's brutal sadism is a result of the patriarchal belief that in a man-woman relation the man is always superior and the woman is inferior. As Foucault (1978: 82) observes about the practices of power characteristic of pre-modern societies, in traditional Indian homes power is centralized and coordinated by a patriarchs who exercise absolute control over each of the family members through the threat or open display of violence. Saru leaves her husband's house and seeks shelter at her father's place where she reflects on her life. She realizes that she will wash away all the guilt and will now go with her husband with new found self -confidence and assertiveness. Sarita presents herself as moving away from normative processes that construct the woman. The events present her will to lead her life in her own terms. She says:

\section{All right, so I'm alone. But so's everyone else. Human beings... they're going to fail you. But because there's just us, because there's no one else, we have to go on trying. If we can't believe in ourselves, we're sunk. ${ }^{4}$}

Thus Saru gains her mental strength. She is no longer hesitant to face her life. She is confident about herself. She has gone beyond the traditional view of a woman as an obedient, demure and meek being. She is no longer doubtful about her potential as a human being. Desai and Deshpande valorize the empowering power of silence. Sarita's silence throughout her life against her mother's tirade, curses, Manohar's physical assault and her broodings over the happenings in a covert way, presents her awareness as well as revolt against the happenings.

\section{Section 1.4 Ila Das in Fire on the Mountain (1977):}

Ila Das is a victim to sexual politics and colonial/patriarchal oppression. In patriarchal set-ups male and female children are looked after discriminately. Women face discrimination right from the childhood. The process of gendering starts from the very beginning of the babies' birth. The birth of male child is celebrated, and the birth of a female baby fills with pain; sons are showered with love, respect, better food and proper health care. Boys are encouraged to be tough and outgoing; girls are encouraged to be home-bound and shy. The parents of Ila Das discriminately sent their three sons to different foreign universities like Heidelberg, Cambridge, and Harvard for

\footnotetext{
${ }^{3}$ Deshpande, Shashi. The Dark Holds No terrors (1990) p.137

${ }^{4}$ Deshpande, Shashi. The Dark Holds No terrors (1990) p.220
}

proper study. Under the pretext of studies these boys wasted their entire father's money on drinks and horse riding. Consequently their father soon plunged into financial crisis and finally succumbed to death stroke. His all three sons even have not bothered to attend the funeral. Anita Desai as such exposes the hollowness of the gender difference. Thus, the onus of the family falls on Ila and her sister Rima. To extend proper care and emotional support to their ailing mother, they did various odd jobs. Even in their abject state male supremacist ideologies prohibited males coming forward and extend their support to Ila Das and her family. Ila Das becomes a social worker. She knows that the stalwarts of patriarchy could not stand her programme of social welfare. As she says:

I do believe the women would listen to me if it wern't for that priest. It's so much harder to teach a man anything, Nanda- the women are willing, poor dears, to try and change their dreadful lives by an effort, but do you think their men will let them? Nooo, not one bit. ${ }^{5}$

Again Ila talks to Nanda, her only friend:

I do think the women would listen to me- if anyone
knows what it is for a girl to be married and been
children at the age of twelve, it's them, isn't it? But
whenever I go, the priest follows me, and undoes
what I do. He hates me, Nanda-ooh, he hates me.

In this way Anita Desai denounces religious priests who follow suit patriarchy. Ila further says that 'in the end, the women listen to them- if not to the priest, then definitely to their husbands ${ }^{7}$. Nevertheless, Ila Das continues her campaign of awareness among illiterate folks undauntedly. She protested Preet Singh a 'sullen lout' 8 by tooth and nail who was ready to marry off his seven years old daughter to a widower having six children to his former wife just at the cost of 'a bit of land and two goats' ${ }^{9}$. Her attempts incurred the displeasure of Preet Singh. In dark, Preet Singh strangulates and then rapes her. After a long battle of life and death, finally, Ila submits herself to the icy hands of death. Foucault identifies the body as the main target of power identification and sexuality as the direct locus of social control:

\begin{abstract}
...what defines a relationship of power is that it is a mode of action that does not act directly and immediately on others. Instead, it acts upon their actions: an action upon an action, on possible or actual future or present actions. A relationship of violence acts upon a body or upon things; it forces, it bends, it breaks, it destroys, or it closes off all possibilities.' (Foucault, 1981:340).
\end{abstract}

\footnotetext{
${ }^{5}$ Desai, Anita. Fire on the Mountain (1977) p.129

${ }^{6}$ Desai, Anita. Fire on the Mountain (1977) p.129

${ }^{7}$ Desai, Anita. Fire on the Mountain (1977) p.129

8 Desai, Anita. Fire on the Mountain (1977) p.130

${ }^{9}$ Desai, Anita. Fire on the Mountain (1977) p.130
} 
Through their work, Desai and Deshpande aspire is to liberate the women colonized at homes, and believe that their freedom can be achieved by providing them education and legal, moral, social protection. Moreover, unlike the Western females, it is the cultural, economic, and religious freedoms that the present Indian women desperately seek.

\section{Section 2.1 Sexual Liberation: Failed Autonomy}

As patriarchy functions as an instrument for the suppression, oppression and exploitation of women, Gokhale's Paro and Manu Kapur's Nisha represent modern women of urban India. Their quest for passion, fame and money is the core of the novels. This female protest is against the system of sexual inequality and institutionalized discrimination. Both the women have been abused sexually in their childhood and this experience leaves an indelible scar on their psyche. Rather than advocating, Kapur and Gokhale are exposing the moral breakdown of modern Indian society. Their women succeed to certain limit in attaining freedom from social bondage but never reach self actualization. As Saru in Darkness Holds no Terror and Nisha in Home believe that through persuasion and their own self-resolution men can be brought around to accepting the equalization of the status of women. Paro is a reactionary feminist with an ideology of vengeance.

\section{Section 2.2 Paro in Paro: Dreams of Passion (1977):}

Paro in the novel exercises power through her sexuality. Paro spends her childhood in the hostel of a remote public school. She is sexually abused in her teens and this experience leaves an indelible scar on her psyche. Paro says about this experience years after, "Funny thing is that I wasn't raped, I loved every moment of it" 10 and also "we were at it, wherever and whenever we could" ${ }^{11}$. She develops a tendency to use the tactical advantage of her sex to obtain a victory in every encounter with a new male. In her quest for self, she mutilates and dominates men whom she encounters. As sexual exploitation has led to psychological oppression of Paro, for Saru, her experience of sex with her husband is no less than that of a rape. Lynne Henderson says:

\section{Rape denies that you are a person, that you exist. In contrast, lovemaking affirms your existence, and undesired sex at least does not completely deny your personhood .... Women experience total helplessness and obliteration during rape. When a woman's existence just does not matter, intercourse becomes rape. (Henderson, 1988:193)}

Paro, in her adulthood, asserts her individual independence by entering into live-in relationship (not yet acceptable in traditional India) with Bucky Bhandpur. "She had left B.R. only six months before-She was living in open adulterous sin with "Bucky Bhandpur", test cricketer. ${ }^{12}$ All her relation-ships with men are for the achievement of

\footnotetext{
${ }^{10}$ Gokhale, Namita. Paro: Dreams of Passion. (1999) p.32

11 Gokhale, Namita. Paro: Dreams of Passion. (1999) p.31

12 Gokhale, Namita. Paro: Dreams of Passion. (1999) p. 27
}

material success and not for emotional fulfillment. Paro, an independent, free thinking and rebellious individual claims her life to be her own, with no commitments or social and moral codes. Her need for self-discovery, self-expression and self-fulfillment have made her questioning. She defies traditions that undermine her individuality. The root of Paro's reactionary feminism lays in her sexual exploitation during her adolescence. Gokhale seems to point out that such psychological oppression, is far worse than the conditions of economic exploitation experienced by middle class not much educated women in India. Paro is a product of male supremacy, and its corollary, sexual exploitation. This kind of male supremacy, itself being reactionary, breeds reaction.

The self awareness and self reliance make her seek liberation through protest to assert herself as a woman and an individual in her own right. On being asked by Priya, her friend and whose husband too she seduces, that how she manages things, Paro says, "It's part of being a Beautiful Woman. It's a full-time occupation and much harder work than it seems" ${ }^{13}$. She realizes that in each relation codified by men -women has only sex as her weapon to gain power. Foucault explains this as:

\section{The notion of sex brought about a fundamental reversal; it made it possible to invert the representation of the relationships of power to sexuality, causing the latter to appear, not in its essential and positive relation to power, but as being rooted in a specific and irreducible urgency which power tries as best it can to dominate. (Foucault, 1978: 155).}

In the end, however, Paro asks herself in the mirror:

\section{Who are you, Paro? I asked myself. And I knew I didn't know. So I started looking for myself again, deciding to follow wherever my search took me. ${ }^{14}$}

Paro who lives with Lenin, flirts with Suresh, marries Loukes, commits suicide in the end. Paro's death seems to suggest that enormous freedom when not managed for meaningful purpose and wasted in unbridled passion leads to destruction. The novel emphasizes the value of equivalence of power. As the novelist exposes in her novel, the cruelty and ugliness of all relationships between Paro and her men as immutable, inescapable ultimately leading her to mess as Paro stands confused and turns self-destructive, it also powerfully expresses the experience and feeling of a whole segment of such radical women population.

\section{Section 2.3 Nisha in Home (1998):}

The protagonist, Nisha in Home, endures a lot of physical, emotional and psychological sufferings. The third generation woman in her family, Nisha, is different from the rest in more than one ways. She does not enjoy cooking and other household jobs. Forced by her mother to remain indoors, this

\footnotetext{
13 Gokhale, Namita. Paro: Dreams of Passion. (1999) p.62

${ }^{14}$ Gokhale, Namita. Paro: Dreams of Passion. (1999) p.109
} 
girl child falls prey to sexual abuse by her own cousin, Vicky. Even her silence and withdrawal fails to draw attention of her mother who tries to indulge her in observing Karva Chauth (fasting for husband's longevity) and the likes. Indians as parents maintain authority of their children for the sake of emphasizing a strong emotional commitment to their families and culture. They bind themselves to their children in sentimental systems of rights and duties and expect their children to respect and obey their judgments about the community and society. In this way they convey and reinforce ideas of pride and respect. Nisha's mother had to confine herself to kitchen, same she expects from her daughter: "This is the life of a woman: to look after her home, her husband, her children, and give them food she has cooked with her own hands." ${ }^{15}$. Nisha's aunt proves to be her savior as she notices the psychological oppression of Nisha at her own home. The abuse she has been put into does not escape her aunt, Rupa's attention. She takes Nisha to her own house, where Nisha gets a healthy and happy life for few years. Nisha enters college, much against her mother's wishes. She falls in love with Suresh, a low caste boy. Though Indian culture does not approve of pre-marital sex, but, Nisha with open-mindedness indulges in physical relations with him.

The Indian society, with its patriarchal legacy, carries a hegemonic masculinity associated to the dominant position of men and the subordination of women. Men in society defend freedom and honour of family and their women. Women on their part, are expected to be supportive, symbolic of family honour and often suppressed. The male dominated society perpetually feels the need of containment and control of female body and thus is always subjected to particular disciplinary techniques. Susan Bordo points out: "the human body is itself a politically inscribed entity, its physiology and morphology shaped by histories and practices of containment and control." (Bordo, 1993:21). Nisha is kept under vigilance, when her intimacy with Suresh is revealed to the family.

\section{All day she remained in the house, a prisoner of her deed, a prisoner of their words. ..A padlock was put on the phone, only incoming calls could be received without the key. ${ }^{16}$}

Nisha does not agree with the collectivistic culture of India that believes the marriage to be union of two families rather than of two individuals. Suresh, however, on being pressurized by his family refuses to marry and deserts her. During this period she lives as a stranger in her own paternal home, as for her age it is the time to be in her husband's place. She feels dejected: 'there is no place for me in this house. If it is only marriage that will get me out then marry me off to anybody, I don't care. ${ }^{17}$. Her feminine sensibility is crushed by patriarchal forces. Strong-willed Nisha completes her study, gets an humble job and craves for a family of her own.

\footnotetext{
${ }^{15}$ Kapur, Manju. Home.(1998) p. 126

${ }^{16}$ Kapur, Manju. Home.(1998) p. 200

${ }^{17}$ Kapur, Manju. Home.(1998) p. 280
}

She is bold, educated and balanced.

Nisha's marriage and motherhood is achieved but not without struggle. She realizes the value of asserting her own self and thus regaining her self-esteem. The quiet acquiescence of the subordinate role in the family gives way to a firm assertion of self-esteem and distinct identity in terms of decolonizing the patriarchal mindset. Foucault has convincingly argued the ways in which individuals in old times were led to constitute or transform their identity and behavior in the light of specific goals set by those who wanted to remain in power. Individuals shaped by their embeddedness in power relations, which means that their capacities for freedom and autonomous action are necessarily limited. Nisha, unlike Paro in Paro: Dreams of Passion creatively transforms herself. Through assertion of her womanhood Nisha survives the traumas in her life. Her actions are not limited to only reacting against power, but she alters power relationships in ways that expands her possibilities for action. She emerges as a business women, when she resolves to resume to her work soon after delivering her duties towards her new born. She realizes that power relations are mutable, flexible and even reversible. Her new patterned attitude to life empowers and also ensures her, to great extent, that variable relations of power do not solidify into states of domination.

\section{Conclusion}

Various inhibitions and encumbrances of women exercising their human rights have found expression in Indian English fiction, especially that written after independence by the women fictionists. Generally, their output has been feministic in portraying the female characters' various reactions to a subsuming life. The selected authors are the careful and fastidious artists with their clear vision of the duty which the writer owes to the society. They firmly grasp the historical dialectics of their society in change. They place the woman at the forefront where she plays major roles to improve on her status and on her society as a whole. Their women are assertive beings seeking recognition and visibility in their society. Patriarchy relegates women to the background at the socio-economic and political levels in the society and looks upon them as objects. These novels do not only expose the poor conditions of women but also celebrate the strong women and their subversion of the patriarchal norms through the exploration of their bodies, desires and sexuality. Their protest is against the injustices and the persecution to which the women in India have always been subjected. Though the rights of women are increasingly being realized, they still remain victims of the prevalent orthodox attitude and male domination, especially in rural region. The selected women authors refuse to unquestionably accept the proposed patriarchal ideology and reflect, analyze and understand in their works, the gender relations and role of power exercised within the structure. They question the dominant patriarchy 
as their protagonists fight for individuality and identity of their own in their rebellion against the established gendered norms. Silence can be a weapon to dismantle the patriarchal mode of writing. Women's writing presents the creative dimension of silence and its potential as a site of protest against patriarchal dominance. Jasbir Jain, an Indian critic highlights this agenda of women's writing in India:

\section{At another level women's writing is the literature of silence. Its meaning lies enclosed and camouflaged. It is also the literature of silence, for it seeks to express that which has been submerged and suppressed. Writing in itself, has always been an act of courage. And women have often resorted to different strategies to say what they wished to get across.(Jain, 1996: 8)}

Such silences keep the avenues open for any action to take place. Education and economic empowerment is now increasingly seen as a process by which the one's without power gain control over their lives. The process of awareness and conscientization of capacity building leads to the transformative action. Thus, empowered women assert themselves and learn to synthesize sociality with individuality within the normative community. In absence of a more culture-specific formulation, the gender discourse in India with just Simone Beauvoir's female-physiology/anatomy-based ideology would remain a partial discourse. Desai, Deshpande, Gokhale and Kapur's narratives represent a segment of contemporary Indian fiction, which is focused on the education and enlightenment of women. Generational differences are seen in all the selected narratives, especially those regarding women's issues. The older women in the novels tend to agree with traditional ideas of gender, while younger women express more contemporary ideas. The authors display sympathy toward their characters and the female condition. They encourage women to change their position in society by resisting their oppressors. Feminine sensibilities of these writers have prompted them to explore that tender area of characters which has been neglected for years in India. These novelists rewrite the colonial text not only to claim voice and history for their people but also contest the postcolonial male narrative by approaching history from a gendered perspective. Through the depiction of their female characters the texts question the attitude of present day India to women, their position in the society and their rights, challenging thus the limits of their freedom. The society, as it is revealed in the texts, is still a traditional one, accepting any change with a great reluctance.

Thus, fiction by Indian English women writers expose the unequal relations between the two sexes; they also challenge men's domination and suggest a deconstruction of the patriarchal system. It can also be said that their characters are 'realist' in the sense that they are fully aware that in order to achieve a limited scope for autonomous action and agency, they need to seek accommodation with prevalent ideological systems, and arrive at an understanding of social responsibility that can supersede gender conflict and their own isolation. In order to achieve equality and resolve tension between the genders, the traditional ideological systems that deprive women of their rights should be reviewed. Women should have the right to determine their own lives. They should have opportunities to achieve independent social and economic existence both in the family as well as in society, if equality is to be achieved. Indian English women writers through psychological probing and sociological concerns, strive to search the secrets of human happiness. Such works inspire the readers to cherish the familial ties in the modern society where the later are degenerating so fast.

The aim of challenging the dominant modes of representation is based on the idea that in a patriarchal society women are not permitted to be in the position of the subject in the sense that women do not have any agency. Today's modern woman juggles between balancing careers and marriage in a male-dominated society. These narratives highlight the economic aspect of this power-play. They stress that there can be no talk of independence for women without economic self-sufficiency. An independent mind or free spirit is meaningless so long as the body and soul are being kept together by somebody else.

\section{REFERENCES}

[1] Barker Chris, Cultural Studies: Theory and Practice. Sage, 2007

[2] Bess, Michael. "Power, Moral Values and the Intellectual: An Interview with Michel Foucault". History of the Present Vol.4 (Spring 1988).

[3] Bordo, S. Unbearable Weight: Feminism, Western Culture and the Body, California: University of California Press. 2004.

[4] Desai, Anita. Clear Light of Day, London: Vintage. 2001.

[5] Desai, Anita. Fire on the Mountain, London: Penguin. 1977.

[6] Deshpande, Shashi. The Dark Holds No terrors, New Delhi: Penguin Books. 1990.

[7] Foucault, Michel, 'Body/Power' and 'Truth and Power' in C. Gordon (ed.) Michel Foucault: Power/Knowledge, U.K.: Harvester. 1980

[8] Foucault, Michel, 'The ethic of care for the self as a practice of freedom' in J. Bernhauer and D. Rasmussen (eds), The Final Foucault, Cambridge: Mass.: MIT Press, 1988b.

[9] Foucault, Michel, The History of Sexuality, translated by R. Hurley, Penguin Books. 1978.

[10] Foucault, Michel. [1981]. "The Subject and Power". In J. Faubion (ed.). Tr. Robert Hurley and others. Power The Essential Works of Michel Foucault 1954-1984, Vol.3 New York: New Press. 2000.

[11] Gokhale, Namita. Paro: Dreams of Passion, New Delhi: 
Penguin Books. 1999.

[12] Henderson, Lynne. 'What Makes Rape a Crime', Estrich, S. Real Rape, Berkeley Women's Law Journal Vol.3, California: University of California Press. 1988.
[13] Jain, Jasbir, ed. Women's Writing: Text and Context, New Delhi : Rawat Publications. 1996.

[14] Kapur, Manju. Home, New Delhi: Penguin India. 1998. 